\title{
Indonesian Maritime Logistics Network Optimization Using Mixed Integer Programming
}

\author{
Arry Rahmawan, Komarudin and Natasha Angelina \\ Department of Industrial Engineering, University of Indonesia, Kampus Baru UI Depok 16424, Indonesia
}

\begin{abstract}
Some causes of the high logistic costs and significant disparity in Indonesia's commodity price is the imbalanced distribution of the flow of goods between west and east regional of Indonesia and the slow development infrastructure. This issue can be happened because maritime transport infrastructure in Indonesia have not served effectively yet,. Therefore, the provider of shipping services should be able to design the Indonesian maritime logistics network that best suits with the current maritime conditions and provide the greatest benefits. This study aims to obtain a model of decision-making at all levels (strategic, tactical, operational) to determine the type of vessel, the shipping routes, and cargo allocation that gives the maximum profit. Main purpose from this study is to develop decision-making model for maritime logistics network design at all levels (strategic, tactical, operational) by using Mixed Integer Programming which can solve the combination of fleet-design, ship-scheduling, and cargo routing problems simultaneously.
\end{abstract}

\section{Introduction}

Based on data from State of Logistics Indonesia (2015), the proportion of Indonesian logistics cost is equivalent to 24.66\% of Gross Domestic Product (GDP) in 2011. Indonesia's Logistic Performance Index (LPI) is on the $5^{\text {th }}$ rank in ASEAN and $53^{\text {rd }}$ of 160 countries in the world which is conducted by the World Bank in 2014.

Indonesia's economic growth in the second quarter of 2015 is increased by $4.67 \%$. From year to year, Indonesia's economic growth tends to be dominated by west regional only which furtherly caused an imbalance distribution of goods between east and west Indonesia. These make costs of logistics and maritime transportation in Indonesia significantly high and resulting in disparity of commodity price in various regions of Indonesia.

Shipping logistics through sea shipping can be divided into three types: liner shipping, tramp shipping, and industrial shipping (Lawrence, 1972). Liner shipping is cargo shipments that have fixed shipping schedule and follow the schedule as the freight shipments schedule. In contrast, tramp shipping does not have a schedule and send cargo shipping available to maximize profits, as well as taxi transportation services. Meanwhile, industrial shipping is managed by shipping cargo-owner who is looking for the lowest cost to send the cargo. In tramp shipping and industrial shipping, type of cargo can be sent in form of container and non container (bulk cargo). This paper will be focused and limited to liner shipping, which container is the type of cargo shipped.

The imbalanced flow of goods, increased logistic and transportation cost is a few of major challenges for stakeholders in the logistics sector, especially the shipping company to design maritime logistic network. In designing the maritime logistics network, particularly in the liner shipping, there are three issues that need to be resolved, namely: fleet design, ship scheduling, and cargo routing (Meijer, 2015). Figure 1 outline the key decisions that need to be made at different levels of the planning horizon. (Agarwal and Ergun, 2008).

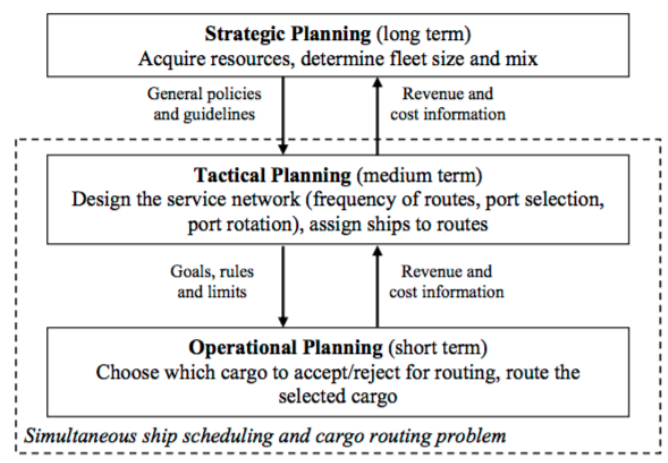

Figure 1. Planning Horizon in Maritime Logistics Network Design

Decision-making horizon is divided into three levels: strategic (3-5 years), tactical (4-12 months), and operational (1-4 weeks) level (Pesenti, 1995). At the strategic level, the decision to be taken is determining fleet design, where the optimal number and type of fleet that is appropriate with maritime conditions need to be determined, as well as in terms of the economy and efficiency. Furthermore, the tactical level, the network should be established shipping routes, especially the 
allocation of shipping routes and ship on each route. Then, at the operational level, the questions to be solved include the allocation of cargo on each shipping route and the number of available fleet. This level needs to decide the most efficient cargo allocation to avoid empty cargo when shipping operations are held.

\section{Research method}

Any problems are interconnected and linked with other problems. Thus, the decision for any problems that are on every level will affect decisions on other issues. Therefore, it is important for these three problems to be solved simultaneously, namely by taking decision simultaneously to all levels of strategic planning, tactical, and operational (Mulder and Dekker, 2013).

The combination of these three problems can be solved by using the Mixed-Integer Programming to determine the type of vessel, the ship scheduling, and cargo allocation. By using the basic principle of an investigational formulation from Mulder and Dekker (2013) which was then developed by Meijer (2015) by adding the calculation of fixed costs and the cost of gasoline consumption for each route on the objective function. Therefore, this study used a formula by Meijer (2015) as a basis to complete the combination of these three issues-design fleet, ship-scheduling, and cargorouting problems.

This study uses 13 ports that have the capacity and facilities to cater for loading and unloading, and classified to the main class and class I port according to the IPC. The ports used in this study are: 1) Belawan ; 2) Tanjung Priok ; 3) Tanjung Perak ; 4) Banjarmasin ; 5) Makassar ; 6) Sorong ; 7) Panjang ; 8) Palembang ; 9) Tanjung Emas; 10) Pontianak; 11) Samarinda; 12) Ambon ; 13) Bitung.

Main point that distinguishes this research with Meijer (2015) is the number of ports used for data input models. Port number used in Meijer (2015) is 6 Indonesian ports. Meanwhile, this study used the whole container terminal in Indonesia, which have 13 ports in total.

Sets:

$$
\begin{aligned}
& h \in H \\
& t \in T \subseteq H \\
& s \in S \\
& j \in J
\end{aligned}
$$

$k \in K$

Parameters:

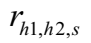

Set of ports

Set of transhipment ports

Set of ship routes

Indicator set denoting whether ship passes both ports $h 1 \in H$ and $h 2 \in H$ on ship route $s \in S$, where $j=\left(h_{1}, h_{2}, s\right)$

Indicator set denoting whether port $h 2 \in H$ is directly visited after port $h 1 \in H$ on ship route $s \in S$, where $k=$ $\left(h_{1}, h_{2}, s\right)$

$r_{h 1, h 2, s}$

Revenue of transporting one TEU from

$h 1 \in H$ to port $h 2 \in H$

$c_{t}^{t}$

Cost of transhipping one TEU in $c_{h}^{h}$

$d_{h 1, h 2}$

$b_{s}$

$I_{h 1, h 2, h 3, h 4, s}^{\text {path }}$

$f_{s}$

dist $_{h 1, h 2}$

$f_{s}^{f}$

Variables:

$x_{h 1, h 2, s}$

$y_{s}$

$x_{h 1, h 2, s}^{o d}$

$x_{h 1, t, h 2, s}^{o t}$

$x_{t 2, h 2, s 1, s 2}^{t d}$

$x_{t 1, t 2, h, s 1, s 2}^{t t}$

Objective Function:

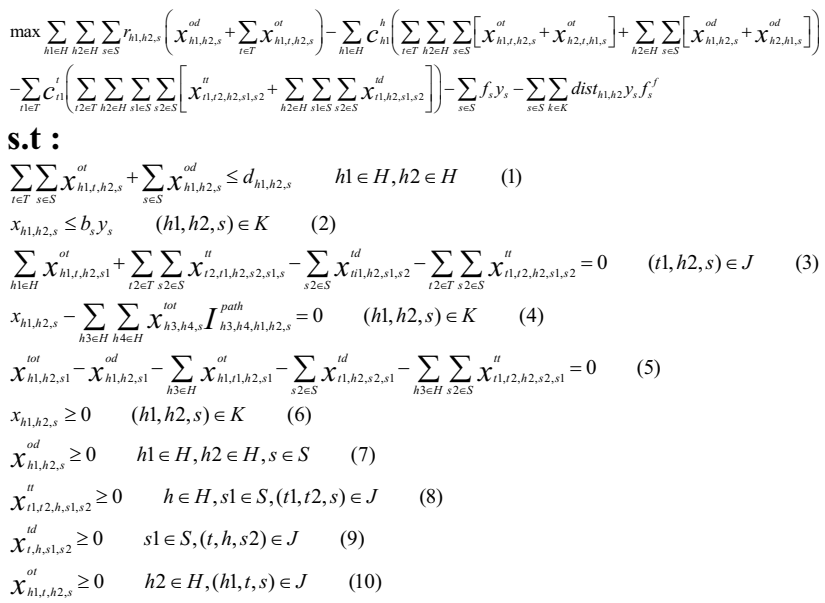

Cost of (un)loading one TEU in origin

or destination port $h \in H$

Demand with origin port $h 1 \in H$ and

destination port $h 2 \in H$

Capacity on ship route $s \in S$

$0 / 1$ parameter that takes the value 1 if a

ship passes consecutive ports $h 2 \in H$ and $h 1 \in H$ when sailing from port $h 1 \in H$ to port $h 2 \in H$ on ship route $s \in S$

Fixed cost of using route $s \in S$

Distance from origin port $h 1 \in H$ to destination port $h 2 \in H$

Fuel price of ship $s \in S$ per nautical mile (nm)

Cargo flow on ship route $s \in S$ between consecutive ports $h 1 \in H$ and $h 2 \in H$ Integer variables that denotes the number of time the routes $s \in S$ is used Direct cargo flow on ship route $s \in S$ between ports $h 1 \in H$ and $h 2 \in H$ Transhipment flow on ship route $s \in S$ between port $h 1 \in H$ and transshipment port $t \in T$ with destination port $h 2 \in H$

Transhipment flow on ship route $s_{2} \in S$ between transhipment port $t \in T$ and destination port $h 2 \in H$ where the flow to transhipment port $t \in T$ was transported on ship route $s_{1} \in S$

Transhipment flow on ship route $s_{2} \in S$ between transhipment port $t_{1} \in T$ and transhipment port $t_{2} \in T$ with destination port $h 2 \in H$, where the flow to transhipment port $t_{1} \in T$ was transported on route $s_{1} \in S$ transhipment port $t \in T$ 
The objective function of this research is to maximize corporate profits, which functions above reflect all revenues minus total cost: fuel cost, transhipment cost, loading / unloading cost, and fixed costs. While the constraints number in this model is 10 (ten) functions, which has the explanations for each function as follows :

Table 1. Constraint Definitions

\begin{tabular}{|c|l|}
\hline Constraint & \multicolumn{1}{|c|}{ Remarks } \\
\hline 1 & $\begin{array}{l}\text { Ensure all cargo shipped on each route } \\
\text { combinations between ports does not exceed } \\
\text { demand level at the port. }\end{array}$ \\
\hline 2 & $\begin{array}{l}\text { Ensure all transshipped cargo on each route does } \\
\text { not exceed the capacity of the ship sailing this } \\
\text { route. }\end{array}$ \\
\hline 3 & $\begin{array}{l}\text { Ensure all cargo which have to be transshipped, will } \\
\text { also be loaded on another route }\end{array}$ \\
\hline 4 & $\begin{array}{l}\text { Define the amount of flow between two consecutive } \\
\text { ports }\end{array}$ \\
\hline 5 & $\begin{array}{l}\text { Define total flow between each two ports in the } \\
\text { same cycle }\end{array}$ \\
\hline $6,7,8,9,10$ & Ensure cargo flow is nonnegative \\
\hline
\end{tabular}

Optimization modeling is using Netbeans IDE 8.0 software and Gurobi. When develop this model, the author makes the set, parameters, variables, objective function and constraint functions as described before. However, to get some parameters in the model, the author calculate some parameter which are different than those described above for input into the model as follows.

1. Calculate the optimum speed by using a formula Brower et al. (2014) for each of these combinations using all types of vessels.

$F_{s}(v)=600 x\left(\frac{v}{v_{s}}\right)^{3} x f_{s} x$ numberdays of sailing $+600 x f_{\text {idle }} x$ number of days in port $F_{s}(v)$ indicates gasoline consumption for each ship routes on the vessel type $\mathrm{s}$ with sailing speed $v$ (nm/hour) and has a design speed of $v_{s}^{*} \cdot F_{s}$ is gasoline consumption (tons/day) when the ship is sailing and $f_{\text {idle }}$ gasoline consumption (tons/day) when the vessel is not used, conducting loading and unloading, or wait for the next trip. The cost of gasoline consumption was \$ $600 /$ ton. The formula above consists of two parts: the calculation of fuel consumption when cruising and calculation of fuel consumption while it is docked in the harbor.

2. Calculate the number of ships needed for each route based on the duration of the trip.

3. Calculate fuel costs per type of vessel for each route by using optimum speeds that have been obtained previously.

4. Calculate weekly fixed cost per type of vessel for each route.

In addition, these models are created using several assumptions:

a. Each port is assumed to have unlimited capacity, so it can serve all types of ships.

b. All types of vessels can bypass each route.

c. Time used by ships while docked to unload or load containers are assumed constant for 24 hours.

d. Sailing speed assumed to be constant, there are no external factors that affect the speed of the ship. e. The level of demand at a port which can not be met by the company will be met by other ports are still in one of the region

\section{Research result}

There are two scenarios in running the optimization model: scenario 1 is an operational condition of the company in general, a condition in which the company decided to serve requests that are considered beneficial and scenario 2 is the condition where the company serves the entire demand arising on all cargo terminals in Indonesia. All model optimize the combination of these 390 round-trip originating from the 13 container ports in Indonesia.

\subsection{Ship-allocation and routes used for Scenario 1}

Optimization models use Netbeans IDE 8.0 software and Gurobi within 11 minutes 40 seconds. Table 2 shows the results of optimization regarding the ship type, routes used, and number of ships needed to meet the weekly demand from origin to destination port in Indonesia. In addition, the optimization model also recommends the speed of the ships based on the distance and time travel for each of these vessels and routes.

Table 2. Ship Types and Routes Used in Scenario 1

\begin{tabular}{|c|c|c|c|}
\hline Ship Type & Routes Used & $\begin{array}{c}\text { Number of } \\
\text { Ships Needed }\end{array}$ & $\begin{array}{l}\text { Optimum } \\
\text { Speed [kn] }\end{array}$ \\
\hline Feeder 450 & $3-11-3$ & 1 & 10,69 \\
\hline Feeder 800 & $1-3-1$ & 2 & 10,33 \\
\hline Feeder 800 & $3-9-3$ & 1 & 10 \\
\hline Panamax_1750 & $1-2-1$ & 2 & 17,73 \\
\hline Panamax 1750 & $2-3-2$ & 1 & 12 \\
\hline Panamax_1750 & $2-5-2$ & 1 & 13,43 \\
\hline Panamax 1750 & $3-4-3$ & 1 & 12 \\
\hline Panamax_1750 & $3-6-3$ & 2 & 12,61 \\
\hline Panamax_2400 & $2-4-2$ & 1 & 12 \\
\hline Panamax_2400 & $3-5-3$ & 1 & 12 \\
\hline Total & 10 & 13 & - \\
\hline
\end{tabular}

According to the table above, if the model is executed on the scenario 1 , the shipping company requires 13 logistics ships consisting of 1 feeder_450, 3 feeder_800, 7 panamax_1750, and 2 panamax_2400. There are 10 shipping routes by serving 8 container ports, which are supposed to provide maximum benefit to the company. The route used can be seen in Table 2 by using the sequence of number corresponding to section 2 above. The ports that can be served by the shipping companies are Belawan, Tanjung Priok, Tanjung Perak, Banjarmasin, Makassar, Sorong, Tanjung Emas, and Samarinda.

The high operating costs and low demand will occur if the company serves some ports outside the served ports above, the remaining 5 ports are not served because they are considered resulting a not optimum condition. Even though Panjang, Palembang, Pontianak, Ambon, and Bitung port are not served by the shipping company, but the demand to the area considered to be supplied by the served ports and is geographically located around the remaining ports. 


\subsection{Ship-allocation and routes used for Scenario} 2

Optimization models use Netbeans IDE 8.0 software and Gurobi within 1 minute 27 seconds. Scenario 2 is made with the intention to see how operational and financial condition of the company if required or seek to serve all demand that appear throughout the container port in Indonesia. If this condition is executed, it is expected to balance the distribution of the flow of goods in the country and eventually reduce domestic logistics costs.

Same as the table 2 on scenario 1, table 3 shows the results of the optimization regarding ship type, routes used, number of ship needed to meet the weekly demand from the origin to destination port in Indonesia, and recommendation on the speed of vessels used.

Table 3. Ship Types and Routes Used in Scenario 2

\begin{tabular}{|l|l|c|c|}
\hline \multicolumn{1}{|c|}{ Ship Type } & Routes Used & $\begin{array}{c}\text { Number of } \\
\text { Ship Needed }\end{array}$ & $\begin{array}{c}\text { Optimum } \\
\text { Speed [kn] }\end{array}$ \\
\hline Feeder_450 & $2-7-2$ & 1 & 10 \\
\hline Feeder_450 & $2-10-2$ & 1 & 10 \\
\hline Feeder_450 & $6-13-6$ & 1 & 10 \\
\hline Feeder_450 & $12-13-12$ & 1 & 10 \\
\hline Feeder_800 & $1-8-1$ & 1 & 11,76 \\
\hline Feeder_800 & $3-4-3$ & 1 & 10 \\
\hline Feeder_800 & $3-8-3$ & 1 & 12,15 \\
\hline Feeder_800 & $3-9-3$ & 1 & 10 \\
\hline Feeder_800 & $3-11-3$ & 1 & 10,69 \\
\hline Panamax_1200 & $3-4-3$ & 1 & 12 \\
\hline Panamax_1750 & $1-2-1$ & 2 & 17,73 \\
\hline Panamax_1750 & $2-3-2$ & 1 & 12 \\
\hline Panamax_1750 & $3-6-3$ & 2 & 12,61 \\
\hline Panamax_2400 & $2-4-2$ & 1 & 12 \\
\hline Panamax_2400 & $3-5-3$ & 1 & 12 \\
\hline Total & $\mathbf{1 5}$ & $\mathbf{1 7}$ & - \\
\hline
\end{tabular}

Based on Table 3, if the model is executed on the scenario 2, the shipping company requires 17 logistics ships consisting of 4 feeder_450, 5 feeder_800 ships, 1 panamax_1200, 5 panamax_1750, and 2 panamax_2400. There are 15 shipping routes, which are supposed to provide maximum benefit to the company by meeting the entire demand from all 13 container ports in Indonesia. This condition is indirectly forcing shipping companies to serve all of the container port, so that the number of ships required increases compared to scenario 1 in order to facilitate shipping operations across the service delivery logistics in Indonesia.

\subsection{Financial and operational scenario comparison}

Financial and operational are two main cosiderations for deciding liner shipping network design.

Figure 2 is a financial comparison of shipping companies in scenario 1 and scenario 2. Scenario 2 had greater revenues and total costs rather than scenario 1 based on Figure 2 because the condition of the companies that seek to serve the entire port container in Indonesia. However, the profit gain is $4.29 \%$ lower than scenario 1 because the shipping company also serve ports which have low demand rate and a very far distance, especially in east regional of Indonesia.

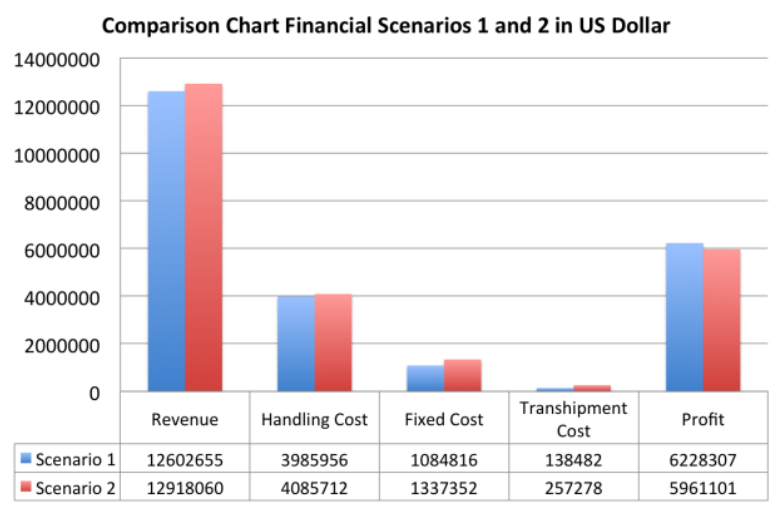

Figure 1. Optimization Result - Financial Condition Scenario 1 and 2

Figure 3 shows the condition for weekly operation scenario 1 where the shipping company is suggested to serve 10 shipping routes from 8 ports by using 13 logistics ships. This condition is the best condition for shipping company to maximize the profit.

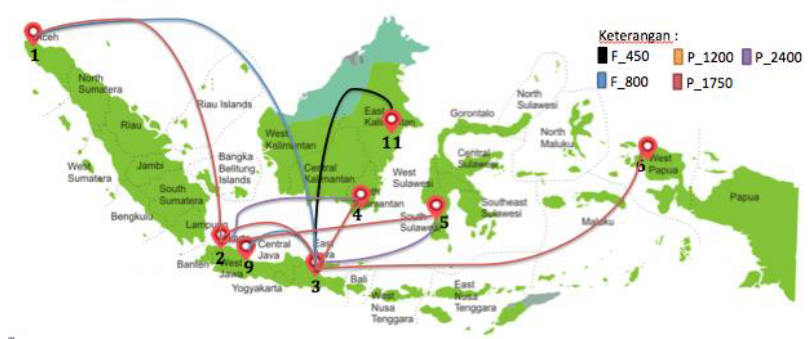

Figure 3. Optimization Result - Operational Condition Scenario 1

Figure 4 shows the operational condition of a shipping company serve the entire container port in Indonesia by using 17 logistics ship and serving 15 shippingg routes.

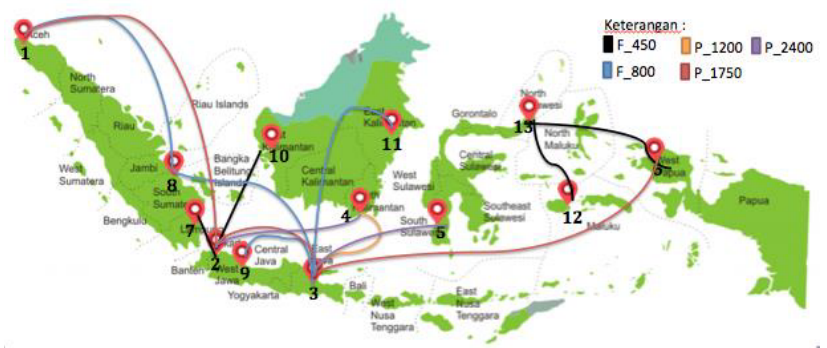

Figure 4. Optimization Result - Operational Condition Scenario 2

Scenario 2 is made with the intention to see how the company's operational and financial condition if companies is trying to serve all demand that appear throughout the container port in Indonesia. In addition, scenario 2 may occur if the government requires the company to serve all ports in west and east regions in Indonesia. It is expected to balance the distribution of goods in the country and eventually reduce domestic logistics costs.

However, after seeing the results issued by the optimization model, it can be seen that scenario 2 shows a greater amount of ship investment rather than scenario 
1. This is why not many shipping companies wishing to serve the entire container port in Indonesia. Therefore, the authors provide recommendations to the government to review the regulation and to consider giving incentives to shipping companies that are willing to serve the container ports that are less profitable, especially those in the East of Indonesia.

\section{Conclusion}

Based on the results and analysis has been explained in previous chapters, mathematical model is the main output from this study. Its function as the decision-making model to design maritime logistics network design at all levels (strategic, tactical, operational) to determine the type of vessel, the ship scheduling and cargo allocation using mixed integer programming. The model optimization was used to compare the impact of route changes on liner shipping company profits.

Based on model output, the maximum benefits can be obtained if the shipping company serve 8 ports : Belawan, Tanjung Priok, Tanjung Perak, Banjarmasin, Makassar, Sorong, Tanjung Emas, and Samarinda with 15 shipping routes and 13 logistics ships consisting of 1 feeder_450, 3 feeder_800, 7 panamax_1750 and 2 panamax_2400. But, if company wants to serve the entire container port in Indonesia, the company is suggested to serve 15 shipping routes and make investments on 17 vessels consisting of 4 feeder_450, 5 feeder_800, 1 panamax_1200, 5 panamax_- 1750 and 2 panamax_2400.

\section{References}

1. Agarwal R, Ergun O. Ship Scheduling and Network Design for Cargo Routing Liner Shipping. Transportation Science. (2016); 00(0):1-3.

2. Badan Pengawas Keuangan dan Pembangunan. Ceta Biru Pengembangan Sistem Logistik Nasional. Jakarta: Badan Pengawas Keuangan dan Pembangunan; 2016.

3. Badan Pusat Statistik [Internet]. Bps.go.id. 2016 [cited 4 November 2016]. Available from: http://www.bps.go.id/linkTabelStatis/view/id/1277

4. Brouer B. A Matheuristic for The Liner Shipping Network Design Problem. Transportation Research Part E. 2014; 42-44.

5. Chiang J. Outlook of Global Container Port Market with Focus on Asia. Dreary Maritime Advisors; 2013 p. 1-28.

6. Chiang J. Market Briefing: Indonesia's Masterplan for Ports, Shipping, and Logistics. Drewry Maritime Advisors; 2015 p. 1-23.
7. Dekker R, Mulder J. Design and Analysis of Container Liner Shipping Networks. Presentation presented at; Erasmus School of Economics, Rotterdam, The Netherlands.

8. Indonesia Sebagai Poros Maritim Dunia [Internet]. Presidenri.go.id. 2016 [cited 5 March 2016]. Available from:

http://presidenri.go.id/maritim/indonesia-sebagaiporos-maritim-dunia.html

9. Dekker R, Mulder J, Kalem H, Meijer J, Warden W, Van Rijn L. Liner Shipping Network Design: The Case of Intra Indonesia Connection. Presentation presented at; Erasmus School of Economics, Rotterdam, The Netherlands.

10. Guericke STierney K. Liner Shipping Cargo Allocation with Service Levels and Speed Optimization. Transportation Research Part E. 2015:40-48.

11. Potret Daya Saing Logistik Indonesia [Internet]. Kemenkeu.go.id. 2015 [cited 13 March 2016]. Available http://www.kemenkeu.go.id/Artikel/potret-dayasaing-logistik-indonesia

12. Kementerian Dalam Negeri. Cetak Biru Pengembangan Sistem Logistik Nasional. Kementerian Dalam Negeri; 2012.

13. Pusat Informasi Harga Pangan Strategis Nasional. (2016, February 15). Beranda: Harga Rata-Rata Komoditas per Provinsi. Retrieved February 15, 2016, from PIHPS Nasional: www.hargapangan.id

14. Kemme N. Container-Terminal Logistics. In: Kemme N, ed. by. Design and Operations of Automated Container Storage Systems. 1st ed. Springer; (2013). p. 9-18.

15. Meijer J. Creating a Liner Shipping Network Design [Post Graduate]. Erasmus University Rotterdam; 2015.

16. Mulder J, Dekker R. Methods for Strategic Liner Shipping Network Design. European Journal of Operational Research. (2013);:367-371.

17. Power T. Proposals for a New Domestic Container Shipping Network in Indonesia. Drewry Maritime Advisory; 2015 p. 1-25.

18. State of Logistics Indonesia 2015. Bandung: Centre of Logistics and Supply Chain Studies, Institut Teknologi Bandung, Asosiasi Logistic Indonesia, STC-Group, World Bank; 2016.

19. Van Rijn L. Service Network Design for Liner Shipping in Indonesia [Postgraduate]. Erasmus University; (2015). 